\section{Perlindungan Hukum Terhadap Pekerja PT. Mara Jaya Dalam Hal Kebebasan Berserikat Menurut Undang-Undang RI Nomor 21 tahun 2000 Tentang serikat pekerja}

oleh :

\section{Jauhari Ginting ${ }^{1}$ Indah Kurnia Ningsih ${ }^{2}$}

\begin{abstract}
Freedom of association and assembly and also expression of opinion are basic rights possessed by citizens of a democratic sovereignty of the people. Based on this, the problem in this thesis is how to regulate the legal protection of workers in terms of freedom of association, how the implementation of legal protection for workers in terms of freedom of association at PT. Mara Jaya, what are the obstacles in terms of freedom of association implementation and how to overcome these obstacles to PT. Mara Jaya.
\end{abstract}

This writing uses the library research method to study secondary data related to the problems and field research by conducting interviews and collecting data to the Chairman of PT. Mara Jaya Medan.

The legal protection arrangement for workers in terms of freedom of association is a guarantee to create a harmonious relationship between workers and employers as partners. Through a healthy industrial relationship, there will be guarantee of an equal position between the worker and the employer, the production process runs smoothly and business activities will not be interrupted and the worker will obtain welfare and guarantee of life until his old age. Implementation of legal protection for workers in terms of freedom of association at PT. Mara Jaya was not initially implemented. However, nowadays, it has been carried out in accordance with the provisions of the legislation that is protecting the rights of members, participating in maintaining order for the continuation of production, distributing aspirations in a democratic manner, developing the skills and

${ }^{1}$ Dosen LLDIKTI dpk Fakultas Hukum UISU. ${ }^{2}$ Alumni Fakultas Hukum UISU. expertise of members, helping to advance the company and fighting for the welfare of members and their families.

Keywords: Legal Protection, Worker, Freedom of Association.

\section{Abstrak}

Kebebasan berserikat dan berkumpul serta menyampaikan pendapat merupakan hak dasar yang dimiliki oleh warga negara dari suatu negarahukum demokratis yang berkedaulatan rakyat. Berdasarkan hal tersebut, maka permasalahan dalam skripsi ini adalah bagaimana pengaturan perlindungan hukum terhadap pekerja dalam hal kebebasan berserikat, bagaimana implementasi perlindungan hukum terhadap pekerja dalam hal kebebasan berserikat di PT. Mara Jaya, apa hambatan pelaksanaan dalam hal kebebasan berserikat dan bagaimana menanggulangi hambatan tersebut terhadap pekerja PT. Mara Jaya.

Penulisan ini menggunakan metode telaah pustaka (library research) untuk mentelaah data sekunder yang berkaitan dengan permasalahan dan penelitian lapangan dengan melakukan wawancara dan pengumpulan data terhadap Ketua Serikat Pekerja PT. Mara Jaya Medan.

Pengaturan perlindungan hukum terhadap pekerja dalam hal kebebasan berserikat merupakan jaminan untuk menciptakan hubungan yang harmonis antara pekerja dengan pengusaha sebagai mitra. Melalui hubungan industial yang sehat akan terjamin kedudukan yang sejajar antara pekerja dengan pengusaha, proses produksi berjalan lancar dan kegiatan usaha tidak tergangu serta pekerja memperoleh kesejahteraan dan jaminan hidup sampai hari tuanya. Implementasi perlindungan hukum terhadap pekerja dalam hal kebebasan berserikat di PT. Mara Jaya awalnya tidak terlaksanakan di PT. Mara Jaya. Namun, seakarang sudah terlaksana sesuai dengan ketentuan perundang-undangan yaitu melindungi hak anggota, turut serta menjaga ketertiban demi kelangsungan produksi Menyalurkan aspirasi secara demokratis, mengembangkan keterampilan dan keahlian 
Media Komunikasi dan Informasi Hukum dan Masyarakat

anggota, ikut memajukan perusahaan dan memperjuangkan kesejahteraan anggota beserta keluarga.

Kata Kunci : Perlindungan Hukum, Pekerja, Kebebasan Berserikat.

\section{PENDAHULUAN}

\section{A. Latar Belakang}

Kebebasan berserikat tercantum dalam Pasal 28 D ayat (2) Amandemen ke 4 UndangUndang Dasar 1945 yakni setiap orang berhak untuk bekerja serta mendapat imbalan dan perlakuan yang adil dan layak dalam hubungan kerja. Pengaturan tersebut sebagai landasan terhadap penggunaan Tenaga Kerja Asing (selanjutnya disebut TKA) di Indonesia terhadap kondisi pasar dalam negeri kebutuhan investasi, kesepakatan internasional dan liberalisasi pasar bebas dengan berkaitan dengan kepentingan nasional untuk memberikan perlindungan terhadap kesempatan tenaga kerja Indonesia.

Pekerja/buruh dalam Pasal 1 ayat (3) Undang-Undang Nomor 13 Tahun 2003 tentang Ketenagakerjaan (selanjutnya disebut UU Ketenagakerjaan) adalah setiap orang yang bekerja dengan menerima upah atau imbalan dalam bentuk lain. Para pekerja yang bekerja di Indonesia selain warga asli juga terdapat orang asing dari negara lain yang biasanya disebut dengan TKA. Sementara yang dimaksud orang asing adalah tiap orang bukan warga Negara Republik Indonesia.

$$
\text { Menurut Pasal } 1 \text { ayat (2) UU }
$$
Ketenagakerjaan, yang dimaksud dengan tenaga kerja adalah setiap orang yang mampu melakukan pekerjaan guna menghasilkan barang dan/atau jasa baik untuk memenuhi kebutuhan sendiri maupun untuk masyarakat" dan Pasal 1 angka (13) bahwa tenaga kerja asing adalah warga negara asing pemegang visa degan maksud bekerja di wilayah Indonesia.

PT. Mara Jaya yang didirikan tahun 1962 berdasarkan akte notaris Ong Kiem Lian, No.109 tertanggal 28 Maret 1962. Akta tersebut disahkan oleh Mentri Kehakiman RI tertanggal 10 Mei 1962 No. J.A. 54720, dengan nama PT. Perusahaan Perkebunan, Dagang Industri Mara Jaya disingkat menjadi PT.Mara Jaya, berkedudukan di Jl. Kepribadian No.7 Medan, dengan memakai cabang-cabang perwakilan di tempat-tempat lain yang ditetapkan oleh direksi memberikan kebebasan kepada pekerjanya untuk membentuk serikat pekerja sebagai wadah untuk menyalurkan aspirasi pekerja. Berdasarkan uraian sebelumnya, masih terlihat banyaknya tenaga kerja di Indonesia yang tidak terpenuhi akan perlindungan hukumnya sedangkan kewajiban harus terus dijalankan, demikian juga tidak adanya kebebasankebebasan pekerja dan hak-hak pekerja untuk ikut serta dalam organisai serikat pekerja untuk memperjuangkan kepentingan pekerja dan keluarganya

\section{B. Rumusan Masalah}

Rumusan masalah dalam penulisan ini adalah :

1. Bagaimana pengaturan perlindungan hukum terhadap pekerja dalam hal kebebasan berserikat?.

2. Bagaimana implementasi perlindungan hukum terhadap pekerja dalam hal kebebasan berserikat di PT. Mara Jaya ?

3. Apa hambatan pelaksanaan dalam hal kebebasan berserikat dan bagaimana menanggulangi hambatan tersebut terhadap pekerja PT. Mara Jaya ? 
Media Komunikasi dan Informasi Hukum dan Masyarakat

\section{Metode Penelitian}

Penelitian ini menggunakan jenis penelitian yuridis normatif. Penelitian yuridis normatif dilakukan dengan cara menelaah dan menginpretasikan hal-hal yang bersifat teoritis yang menyangkut asas, konsepsi, doktrin dan norma hukum yang bersangkutan dengan perlindungan hukum terhadap pekerja dalam hal kebebasan berserikat.

Penelitian yuridis normatif adalah pendekatan yang dilakukan berdasarkan bahan hukum utama dengan cara menelah teori-teori, konsep-konsep, asas-asas serta peraturan perundang-undangan yang berhubungan dengan penelitian ini.

Berdasarkan sifatnya maka penelitian bersifat deskriptif yaitu bermaksud untuk memberikan gambaran secara jelas dan terprinci mengenai tinjauan.

Dalam penelitian hukum normatif bahan pustaka merupakan dasar yang dalam (ilmu) penelitian digolongkan sebagian data sekunder. Data sekunder dalam penelitian ini dapat dibedakan menjadi 3 bagian :

a. Bahan Hukum Primer dalam penelitian ini adalah bahan hukum yang berkekuatan mengikat yakni Undang-undang Dasar Negara Republik Indonesia, Undangundang Nomor 39 tahun 1999 Tentang Hak Asasi Manusia, ILO Nomor 87 Tahun 1948, Undang-undang Nomor 13 Tahun 2003 Tentang Ketenagakerjaan, Undang-undang Nomor 21 Tahun 2000 Tentang Serikat Pekerja/serikat buruh.

b. Bahan Hukum Sekunder merupakan bahan yang memberikan penjelasan mengenai bahan hukum primer,seperti rancangan Undang-Undang hasil penelitian dapat berupa pakar hukum serta buku-buku yang berkaitan dengan perlindungan hukum terhadap pekerja dalam hal kebebasan berserikat.

a) Bahan Hukum Tersier merupakan yang memberikan penjelasan mengenai bahan hukum primerdan bahan hukum sekunder seperti kamus, ensiklopedia serta artikel dari internet.

Teknik pengumpulan data yang digunakan adalah studi kepustakaan. Studi kepustakaan yang dilakukan oleh peneliti untuk menghimpun informasi dapat diperoleh dari buku-buku ilmiah, penelitian, karangan ilmiah, tesis dan disertai peraturan-peraturan, ketetapan-ketetapan, buku tahunan, ensiklopedia dan sumber-sumber tertulis baik tercetak maupun elektronik.

Analisis data yang digunakan dalam penelitian ini adalah analisis secara kualitatif yaitu uraian yang dilkukan peneliti terhadap data yang terkumpul tidak menggunakan statistik atau matematika ataupun sejenisnya tetapi berupa uraian-uraian kalimat yang tersusun secara sistematis sesuai dengan permaslahan yang dibahas dalam penelitian ini.

Dalam menarik kesimpulan penulis menggunakan metode dedukatif yaitu merupakan cara berfikir yang menarik kesimpulan dari suatu pernyataan atau dalil yang bersifat umum menjadi suatu pernyataan yang bersifat khusus.

\section{Hasil Penelitian dan Pembahasan}

\section{A. Pengaturan Perlindungan Hukum} Terhadap Pekerja dalam Hal Kebebasan Berserikat

1. Undang-undang Dasar Negara Republik Indonesia

Pekerja secara individual berada dalam posisi lemah dalam memperjuangkan haknya. Dengan pelaksanaan prinsip kebebasan 
Media Komunikasi dan Informasi Hukum dan Masyarakat

berserikat, dapat diwujudkan dengan menjadi anggota dalam serikat pekerja. Berada dalam serikat pekerja, dapat meningkatkan posisi tawar pekerja. ${ }^{3}$

Pengakuan kebebasan berserikat tercantum dalam Pasal 28E ayat (3) UUD Tahun 1945 yakni setiap orang berhak atas kebebasan berserikat, berkumpul dan mengeluarkan pendapat. Prinsip kebebasan berserikat tidak hanya diatur di dalam konstitusi Indonesia, melainkan juga tercantum dalam Pasal 24 ayat (1) dan (2).

Prinsip kebebasan berserikat berfungsi sebagai hak dasar bagi pekerja untuk berorganisasi dan membentuk serikat pekerja termasuk dalam lapangan hukum perburuhan. ${ }^{4}$

Pemerintah berfungsi sebagai pihak yang mengawasi kebebasan tersebut, dengan maksud apabila terjadi pelanggaran yang dilakukan oleh pekerjaataupun serikat buruh dalam pelaksanaan kebebasan berkumpul, pemerintah atas dasar peraturan perundangundangan yang berkewajiban untuk menindak secara tegas pelanggaran tersebut.

Tindakan pemerintah tersebut tidak termasuk tindakan yang menghalang-halangi pelaksanaan kegiatan serikat buruh namun lebih kepada tindakan penertiban serta pencegahan pelanggaran lebih lanjut. Oleh karena itu agar dapat dibatasi campur tangan pemerintah dalam kebebasan berkumpul, sebaiknya pekerja atau serikat buruh mematuhi dan melaksanakan peraturan perundang-undangan yang memuat tata cara pelaksanaan kebebasan berkumpul

\footnotetext{
${ }^{3}$ Asri Wijayanti, Hukum Ketenagakerjaan Pasca Reformasi, Sinar Grafika, Jakarta, 2009, hal. 71.

${ }^{4}$ Bahder Johan Nasution, Hukum Ketenagakerjaan Kebebasan Berserikat Bagi Pekerja, Mandar Maju, 2004, hal. 4.
}

serta memastikan kebebasannya tersebut tidak mengganggu masyarakat atau ketertiban umum.

Setiap pekerja yang tergabung dalam serikat buruh berhak untuk mengutarakan pendapatnya dengan kalimat yang tidak menyinggung, tidak menghina atau merendahkan pekerja lainnya serta harus menghormati kebebasan berpendapat pekerja lainnya. Sebagaimana tercantum dalam Pasal 28 UUD Tahun 1945, pelaksanaan kebebasan mengeluarkan pendapat adalah dengan cara lisan dan tulisan.

\begin{abstract}
Berpendapat secara tulisan dapat diekspresikan dengan melalui pers seperti surat kabar, majalah juga jurnal-jurnal ilmiah, baik yang berhubungan dengan pekerja maupun untuk masyarakat umum. Sedangkan kebebasan untuk mendirikan organisasi atau kelompok berkaitan erat dengan kebebasan berkumpul dan mengeluarkan pendapat. ${ }^{5}$
\end{abstract}

2. Undang-undang Nomor 39 tahun 1999 Tentang Hak Asasi Manusia

Undang-Undang Nomor 39 Tahun 1999

Tentang Hak Asasi Manusia (selanjutnya disebut UU Hak Asasi Manusia) yang merupakan hak atas kebebasan pribadi memberikan hak untuk berserikat.

Hak berserikat bagi pekerja merupakan perwujudan dari hak-hak dasar manusia sebagaimana diatur dalam Pasal 28 UUD 1945. Hak berserikat dalam hukum ketenagakerjaan secara penuh memberikan kebebasan kepada pekerja untuk berorganisasi dan membentuk serikat-serikat pekerja. Pembentukan dan kegiatan serikat pekerja dalam hubungan industrial mendapat pengaturan secara nasional dan internasional, baik dalam hukum

\footnotetext{
${ }^{5}$ Ibid, hal. 25.
} 
Media Komunikasi dan Informasi Hukum dan Masyarakat

ketenagakerjaan maupun dalam berbagai konvensi perburuhan internasional. $^{6}$

\section{ILO Nomor 87 Tahun 1948}

Pasal 8 ILO Nomor 87 Tahun 1948 menyatakan bahwa dalam melaksanakan hakhak dan kebebasan yang diatur dalam konvensi tersebut, pekerja dan pengusaha harus tunduk pada hukum yang berlaku pada negara yang meratifikasi konvensi tersebut, yang dalam hal ini adalah Indonesia maka yang berlaku Undang-undang Dasar Tahun 1945 dan peraturan perundang-undangan lainnya.

Kalimat tanpa pembedaan apapun dikaitkan dengan yang tercantum dalam UUD Tahun 1945 yakni setiap orang, maka kebebasan berserikat ditujukan tanpa adanya diskriminasi jenis kelamin, warna kulit, suku bangsa, kepercayaan, dan kewarganegaraan. Sehingga apabila diartikan, warga negara Indonesia dan warga negara asing dalam hal ini pekerja asing dapat pula mendirikan serikat dan bergabung menjadi anggota serikat buruh. ${ }^{7}$

4. Undang-undang Nomor 13 Tahun 2003 Tentang Ketenagakerjaan

Keberadaan tenaga kerja dan pengusaha diatur dalam pasal 104 ayat (1) UU Ketenagakerjaan dinyatakan bahwa setiap pekerja/buruh, demikian juga sebaliknya dalam pasal 105 ayat (1) dinyatakan bahwa pengusaha berhak membentuk dan menjadi anggota organisasi pengusaha.

Sesuai dengan pasal 104 ayat (1) UU Ketenagakerjaan, membentuk serikat pekerja merupakan hak dari semua pekerja/buruh. Penjelasan pasal 104 ayat (1) UU Ketenagakerjaan menjelaskan bahwa

${ }^{6}$ Bahder Johan Nasution, Fungsi Kebebasan Berserikat Bagi Pekerja Dalam Hubungan Industrial Pancasila, Jurnal Inovatif, Volumen Nomor 1 Tahun 2015, hal. 4.

${ }^{7}$ Ida Hanifah Lubis, Pengantar Hukum Ketenagakerjaan di Indonesia, Ratu Jaya, Jakarta, 2009, hal. 73. kebebasan untuk membentuk, masuk atau tidak masuk menjadi anggota serikat pekerja/serikat buruh merupakan salah satu hak dasar pekerja/buruh. Ketentuan lebih lanjut mengenai serikat pekerja/serikat buruh ini diatur dalam Undang-undang Nomor 21 Tahun 2000.

5. Undang-undang Nomor 21 Tahun 2000 Tentang Serikat Pekerja/serikat buruh.

Pasal 5 UU Serikat Pekerja/Serikat Buruh menyebutkan bahwa setiap pekerja berhak membentuk dan menjadi anggota serikat buruh. Pekerja adalah setiap orang yang bekerja dan menerima upah atau imbalan dalam bentuk lain. UU Ketenagakerjaan menyebutkan bahwa yang termasuk pekerja tidak hanya pekerja berkewarganegaraan Indonesia saja, melainkan pekerja asing. Dengan demikian menyiratkan bahwa pekerja asing juga dapat membentuk dan menjadi anggota dalam serikat buruh di Indonesia.

Menurut Asri Wijayanti menyebutkan bahwa :

Serikat pekerja hanya dapat didirikan oleh dan untuk warga negara Indonesia. Serikat buruh dibentuk dengan berdasarkan Pancasila sebagai dasar negara dan Undang-undang Dasar 1945 sebagai konstitusi Indonesia. Sedangkan pengusaha yang mempekerjakan pekerja asing hanya untuk jabatan tertentu dan waktu kerja tertentu, sehingga untuk pekerjaan dalam waktu tertentu menggunakan perjanjian kerja waktu tertentu, di mana pekerjaannya tidak bersifat tetap. Pekerja asing tetap sebagai warga negara asing, oleh karena itu pekerja asing tidak menggunakan Pancasila dan Undang-undang Dasar 1945 sebagai dasar negara dan konstitusi. Sehingga tidak mungkin pekerja asing dapat membentuk serikat buruh di Indonesia mengingat pekerja asing tidak menggunakan Pancasila dan Undangundang Dasar $1945 .^{8}$

Berdasarkan hal di atas, maka pembentukan tujuan serikat pekerja sebenarnya

${ }^{8}$ Asri Wijayanti, Op. Cit, hal. 87. 
Media Komunikasi dan Informasi Hukum dan Masyarakat

masih banyak dipengaruhi oleh pemerintah yakni melalui undang-undang. Tujuan didirikannya serikat buruh diatur secara garis besar namun mencakup segalanya dalam Pasal 4 ayat (1) UU Serikat Pekerja/Serikat Buruh yakni serikat buruh bertujuan untuk :

1. Memberikan perlindungan.

2. Melakukan pembelaan hak dan kepentingan.

3. Meningkatkan kesejahteraan yang layak bagi pekerja dan keluarganya. ${ }^{9}$

Ketiga tujuan tersebut sangat krusial dan merupakan inti dari didirikannya serikat buruh. Inilah suatu bentuk kebebasan yang masih sangat dipengaruhi oleh pemerintah, meskipun nyatanya kebebasan tersebut tidak dilanggar karena undang-undang memang mempunyai wewenang untuk membatasinya. Agar tujuan-tujuan dapat tercapai maka dibutuhkan fungsi pelaksananya yakni :

a. Sebagai pihak dalam pembuatan perjanjian kerja bersama dan penyelesaian hubungan industrial.

b. Sebagai wakil pekerja dalam lembaga kerjasama di bidang ketenagakerjaan sesuai tingkatannya.

c. Sebagai sarana menciptakan hubungan industrial yang harmonis dan berkeadilan.

d. Sebagai penyalur aspirasi dalam memperjuangkan hak dan kepentingan anggotanya.

e. Sebagai perencana, pelaksana dan penanggung jawab pemogokan kerja.

f. Sebagai wakil pekerja dalam memperjuangkan kepemilikan saham dalam perusahaan.

Satu-satunya pihak yang dapat mewakili pekerja dalam perundingan dan pembentukan

\footnotetext{
${ }^{9}$ Asri Wijayanti, Ibid, hal. 88.
}

perjanjian kerja bersama dengan pengusaha adalah serikat pekerja/serikat buruh, sehingga di sinilah peran penting serikat pekerja/serikat buruh muncul. Perjanjian kerja bersama biasanya tercantum klausula yang mendukung kepentingan pekerja/buruh. Meskipun di dalam satu perusahan terdapat lebih dari satu serikat pekerja/serikat buruh, masing-masing serikat pekerja/serikat buruh tersebut juga berhak menyalurkan aspirasi anggotanya dalam perundingan perjanjian kerja bersama dengan pengusaha. Ketika perundingan, peran aktif masing-masing perwakilan serikat buruh sangat diperlukan demi memperjuangkan tujuan masing-masing.

Serikat pekerja/serikat buruh dapat berperan sebagai wakil pekerja dalam lembaga kerjasama seperti lembaga kerjasama bipartit, tripartit, serta lembaga yang bersifat tripartit lainnya seperti Dewan Pelatihan Kerja Nasional, Dewan Keselamatan Kerja, dan Dewan Penelitian, di mana serikat pekerja/serikat buruh bersama lembaga-lembaga tersebut akan membahas mengenai kebijakan yang berkaitan dengan ketenagakerjaan. ${ }^{10}$

Serikat pekerja/serikat buruh juga berperan serta dalam memperjuangkan kepemilikan saham pekerja pada perusahaan. Pembelian saham perusahaan merupakan hak setiap orang oleh karena itu pekerja sebenarnya dapat membeli saham perusahaan tempatnya bekerja. Terkadang pekerja secara individual tidak mendapatkan perhatian lebih dari pengusaha sehingga dalam memperjuangkan kepemilikan saham dibutuhkan perwakilan pekerja yakni serikat pekerja/serikat buruh.

\footnotetext{
${ }^{10}$ Ibid, hal. 89.
} 
Media Komunikasi dan Informasi Hukum dan Masyarakat

\section{B. Implementasi Perlindungan Hukum}

Terhadap Pekerja dalam Hal Kebebasan

Berserikat di PT. Mara Jaya

Kebebasan yang mendasari prinsip kebebasan berserikat adalah kebebasan untuk berkumpul dan berpendapat serta berekspresi, kebebasan untuk mendirikan dan bergabung dalam organisasi atau kelompok, serta kebebasan untuk menjalankan fungsi administrasi organisasi atau kelompok, membuat aturan organisasi atau kelompok dan menjalankan kegiatannya, di mana kebebasankebebasan tersebut tidak bersifat mutlak karena dibatasi oleh peraturan perundang-undangan.

Prinsip kebebasan berserikat diaplikasikan melalui serikat buruh yang mempunyai tujuan utama yakni memperjuangkan hak-hak dan kesejahteraan pekerja, terutama pekerja yang menjadi anggota serikat buruh tersebut.

Kebebasan berserikat bagi pekerja merupakan hak dasar yang diatur dalam konstitusi, oleh karenanya wajar secara hukum apabila hak tersebut dilindungi dan dijamin pelaksanaannya. Dalam hubungan industrial Pancasila kebebsan berserikat bagi pekerja selain berfungsi untuk instrumen tawar menawar dengan pengusaha juga berfungsi sebagai sarana perjuangan hak-hak pekerja.

Tujuan yang ingin dicapai dalam hubungan industrial, adalah mewujudkan masyarakat adil dan makmur dengan cara menciptakan ketenangan bekerja dan berusaha yang dilandasi dengan prinsip kemitraan dan keseimbangan, berasaskan kekeluargaan dan gotong royong serta musyawarah untuk mencapai mufakat. Asas kekeluargaan dan gotong royong serta asas musyawarah mufakat ini secara filosofis merupakan landasan bagi sikap mental dan sikap sosial dalam hubungan industrial. ${ }^{11}$

Fungsi hak berserikat bagi pekerja dalam hubungan industrial, bertolak dari dua permasalahan yang sangat mendasar yaitu :

1. Fungsi kebebasan berserikat sebagai instrumen perjuangan hak bagi pekerja dalam hubungan industrial Pancasila.

2. Perjuangan kebebasan berserikat bagi pekerja di Negara-negara berkembang.

Secara umum, masalah-masalah pokok hubungan industrial di Indonesia telah mendapat pengaturan dalam hukum ketenagakerjaan. Pengaturan tersebut dimaksudkan sebagai upaya untuk meningkatkan kualitas perlindungan kerja sesuai dengan harkat dan martabat kemanusiaan, serta sebagai landasan untuk menciptakan ketenangan kerja yang berkeadilan sosial dan perlindungan terhadap hak-hak pekerja seperti hak berserikat bagi pekerja.

Dilihat dari segi fungsinya, serikat pekerja merupakan sarana kanalisasi untuk menyampaikan hasrat, harapan, keluhan, saran atau kritik pekerja terhadap pengusaha. Dalam sistem manajemen modern, sangat ditekankan pentingnya pendekatan kemanusiaan (human approach) dalam menumbuhkan motivasi pekerja. Selain itu jalur-jalur semi formal dan jalur non formal yang ada di perusahaan merupakan mekanisme yang sangat efektif melebihi jalur struktural yang khirarkis. Dalam hal ini serikat pekerja berfungsi sebagai jalur semi formal. Melalui serikat pekerja, harapan, petunjuk dan informasi dari perusahaan dapat disampaikan dengan baik kepada pekerja. $^{12}$

11 Sukarno, Pembaharuan Gerakan Buruh di Indonesia dan Hubungan Perburuhan Pancasila, Alumni, Bandung, 2009, hal. 135.

12 Yunus Shamad, Hubungan Industrial di Indonesia, Bina Sumber Daya Manusia, Jakarta, 2005, hal. 49. 
Media Komunikasi dan Informasi Hukum dan Masyarakat

Keberadaan hak berserikat yang diwujudkan dalam bentuk serikat pekerja dalam hubungan industrial mempunyai dua fungsi pokok yaitu :

1. Berfungsi untuk melindungi pekerja dengan ikut berperan menetapkan standar-standar minimum tentang upah, kesehatan kerja, jaminan sosial dan jam kerja bagi pekerja.

2. Mengatur hubungan kerja antara pengusaha, pekerja dan pemerintah dengan jalan menetapkan peraturan dalam bentuk Kesepakatan Kerja Bersama (KKB), dengan tujuan merobah peran pekerja dari yang semula sebagai suatu obyek menjadi mitra kerja dalam proses produksi. ${ }^{13}$

Menurut UU Ketenagakerjaan yang tertuang dalam Pasal 102 ayat (2) dalam melaksanakan hubungan industrial serikat pekerja mempunyai fungsi yaitu :

1. Melindungi hak anggota

Serikat pekerja yang telah mempunyai nomor pencatatan mempunyai kewajiban terhadap anggotanya. Adapun kewajiban serikat pekerja menurut UU Serikat pekerja/serikat buruh adalah membela anggota dari pelanggaran hak, memperjuangkan kepentingannya dan memperjuangkan peningkatan kesejahteraan anggota dan keluarga.

2. Turut serta menjaga ketertiban demi kelangsungan produksi

Kelangsungan produksi akan dapat berjalan dengan baik apabila ada ketertiban dan kedisiplinan dari para pekerja. Serikat pekerja PT. Mara Jaya Perkebunan Batu Rata Kecamatan Bangun Purba turut serta menjaga ketertiban dangan cara melaksanakan semua peraturan yang ada di perusahaan PT. Mara
Jaya Perkebunan Batu Rata Kecamatan Bangun Purba dan Undang Ketenagakerjaan dan Undang-undang serikat pekerja.

\section{Menyalurkan aspirasi secara demokratis}

Serikat pekerja sebagai organisasi yang mewadahi para pekerja di perusahaan berfungsi sebagai lembaga penyalur aspirasi. Hal itu juga menjadi pendorong utam para pekerja di PT. Mara Jaya Perkebunan Batu Rata Kecamatan Bangun Purba untuk masuk menjadi anggota serikat pekerja.

Denga masuk menjadi anggota serikat pekerja, maka pekerja mempunyai kesempatan yang lebih besar untuk didengar. Contoh penyalur aspirasi pekerja yang dilakukan ialah kenaikan gaji sesuai dengan Upah Minimum Kota (UMK) dan Kebutuhan Hidup Minimum (KHM).

4. Mengembangkan keterampilan dan keahlian anggota

Peningkatan kualitas sumber daya manusia bukan hanya tanggung jawab perusahaan saja tetapi tanggung jawab semua pihak tak terkecuali serikat pekerja. Serikat pekerja di PT. Mara Jaya Perkebunan Batu Rata Kecamatan Bangun Purba meningkatkan pengetahuan anggotanya dalam berbagai bidang. Adapun bidang yang digarap oleh serikat pekerja adalah bidang ekonomi, politik dan olah raga. Dalam bidang ekonomi, para anggota diberi pembekalan tentang UU Ketenagakerjaan. Dalam bidang politik para anggota diberi pembekalan dari Dewan Pimpinan Cabang Serikat Pekerja tentang kepemimpinan. Sedangkan dalam bidang olah raga serikat pekerja memberikan kebebasan kepada para anggotanya untuk mengasah bakat yang mereka miliki.

${ }^{13}$ Ibid, hal. 52. 
Media Komunikasi dan Informasi Hukum dan Masyarakat

5. Ikut memajukan perusahaan

Serikat pekerja di PT. Mara Jaya Perkebunan Batu Rata Kecamatan Bangun Purba turut serta dalam usaha peningkatan produktifitas dan semangat kerja para anggotanya. Hal itu dibuktikan dengan adanya penilaian produktifitas kerja setiap enam bulan sekali. Serikat pekerja turut serta secara aktif dalam peningkatan afisiensi, efektifitas, produktifitas dan semangat kerja para pekerja. Penilaian tersebut akan membuat semangat kerja dapat meningkat yang diikuti pula dengan meningkatnya hasil produksi.

6. Memperjuangkan kesejahteraan anggota beserta keluarga

Salah satu tujuan pembentukan serikat pekerja menurut UU Serikat Pekerja/Serikat Buruh adalah meningkatkan kesejahteraan anggotanya. Kesejahteraan identik dengan isuisu ekonomi yang meliputi gaji, jam kerja, tunjangan, cuti dan kesehatan dan keselamatan kerja. Kesejahteraan anggota telah menjadi perhatian utama dalam kegiatan serikat pekerja.

Serikat pekerja di PT. Mara Jaya Perkebunan Batu Rata Kecamatan Bangun Purba memperjuangkan kesejahteraan anggotanya dengan cara mendesak perusahaan agar memberikan upah sesuai dengan Upah Minimum Kota (UMK) dan Kebutuhan Hidup Minimun (KHM). Selain itu serikat pekerja PT. Mara Jaya Perkebunan Batu Rata Kecamatan Bangun Purba juga mengawasi pelaksanaan PKB.

\section{Hambatan Pelaksanaan dalam Hal Kebebasan Berserikat dan Menanggulangi Hambatan Terhadap Pekerja PT. Mara Jaya}

Menciptakan hubungan industrial yang harmonis antara pekerja dengan pengusaha sangatlah penting, sebab dengan terciptnya hubungan industrial yang harmonis akan meningkatkan produktivitas kerja perusahaan. Namun demikian tidak mudah dalam menciptakan hubungan industrial yang harmonis. Ada dua hambatan yang dihadapi oleh serikat pekerja PT. Mara Jaya Perkebunan Batu Rata Kecamatan Bangun Purba dalam pelaksanaan hal kebebasan berserikat pekerja yaitu hambatan internal dan hambatan eksternal. Kedua hambatan tersebut diuraikan sebagai berikut :

1. Hambatan Internal

Hambatan internal adalah hambatan yang berasal dari dalam serikat pekerja dan hambatan tersebut dapat berupa :
a. Faktor Sumber Daya Manusia
b. Kurangnya Komunikasi
c. Minimnya dana
2. Hambatan Eksternal

Hambatan eksternal adalah hambatan yang berasall dari luar serikat pekerja, yang berupa Hambatan dari perusahaan, Hubungan industrial yang harmonis akan tercipta jika pekerja dan pihak perusahaan saling memahami hak dan kewajiban masing-masing pihak. Hal itu dibuktikan dengan pemberian hak pekerja sesuai dengan peraturan yang berlaku akan tetapi terkadang perusahaan menghambat serikat pekerja.

1. Upaya Untuk Mengatasi Hambatan Internal

a. Faktor Sumber Daya Manusia

Serikat pekerja PT. Mara Jaya Perkebunan Batu Rata Kecamatan Bangun Purba berusaha untuk bekerja secara profesional dengan meningkatkan kualitas Sumber Daya Manusia melalui pelatihan dan pendidikan. Dengan 
Media Komunikasi dan Informasi Hukum dan Masyarakat

adanya pelatihan dan pedidikan tersebut diharapkan dapat menambah pengetahuan pekerja.

\section{b. Kurangnya Komunikasi}

Komunikasi yang baik harus terus dibangun sehingga Serikat Pekerja PT. Mara Jaya Perkebunan Batu Rata Kecamatan Bangun Purba berusaha mengatasi hambatan komunikasi dengan cara perwakilan tiap departemen. Sebagaimana dikemukakan oleh Nurliansyah Wakil Pimpinan Serikat Buruh PT. Mara Jaya Perkebunan Batu Rata Kecamatan Bangun Purba bahwa usaha untuk membangun komunikasi dengan cara kalau rapat mengundang perwakilan dari tiap departemen caranya engan melibatkan kepala regu. Kepala regu itu akan memberitahukan hasilnya ke tiaptiap departemen. ${ }^{14}$

\section{c. Minimnya dana}

Dana Serikat Pekerja PT. Mara Jaya Perkebunan Batu Rata Kecamatan Bangun Purba berasal dari iuran anggota. Dana yang ada selama ini hanya bisa untuk melaksanakan operasional sehari-hari. Oleh karena itu pada pengurusan 2019 ini iuran anggota dinaikkan menjadi $1 \%$ dari gaji pokok. Hal ini sesuai yang disampaikan oleh Nurliansyah Pimpinan Serikat Pekerja PT. Mara Jaya Perkebunan Batu Rata Kecamatan Bangun Purba bahwa terkendala masalah dana tahun 2019 maka menaikkan iuran supaya program eksternal dapat terwujud. luran yang sekarang masih terlalu kecil belum sesuai dengan dasar anggaran rumah tangga Serikat Pekerja PT. Mara Jaya Perkebunan Batu Rata Kecamatan Bangun Purba sehingga berusaha untuk bisa ke arah sana supaya dapat

${ }^{14}$ Hasil Wawancara dengan Nurliansyah, Wakil Pimpinan Serikat Buruh PT. Mara Jaya Perkebunan Batu Rata Kecamatan Bangun Purba, Senin 08 Juli 2019 Pukul $10.00 \mathrm{Wib}$. menghidupi organisasi tanpa bantuan dari pihak lain. ${ }^{15}$

2. Upaya untuk mengatasi hambatan eksternal Menurut hasil wawancara dengan Nurliansyah Wakil Pimpinan Serikat Buruh PT. Mara Jaya Perkebunan Batu Rata Kecamatan Bangun Purba bahwa cara menghadapi perselisihan secara prosedural dalam hal ini pengurus serikat pekerja meminta penjelasan dari manjemen, serikat pekerja memberikat surat ke managemen minta penjelasan secara detail dari pihak managemen dan jika tidak selesai maka dilanjutkan Bipartit, lalu ke dinas ketenagakerjaan, apabila belum selesai juga serikat pekerja membawa masalah tersebut ke lembaga yang lebih tinggi lagi.

Dalam menjalani mediasi tripartit di dinas ketenagakerjaa tersebut pihak dinas ketenagakerjaan memberikan arahan sehingga pihak perusaaan menyetujui pekerjanya untuk ikut serta dalam serikat serbundo, dan untuk yang di PHK dilakukan pada pekerja yang sudah dekat masa pensiun.

\section{Kesimpulan Dan Saran}

\section{A. Kesimpulan}

1. Pengaturan perlindungan hukum terhadap pekerja dalam hal kebebasan berserikat dalam hubungan industrial diatur menurut Undang-undang Nomor 21 Tahun 2000 Tentang serikat pekerja yang memberikan ruang dan jaminan perlindungan hukum bagi pekerja untuk membentuk dan menjadi anggota serikat pekerja sebagai wadah organisasi dalam rangka membina hubungan kerja antara pekerja dengan

15 Hasil Wawancara dengan Nurliansyah, Wakil Pimpinan Serikat Buruh PT. Mara Jaya Perkebunan Batu Rata Kecamatan Bangun Purba, Senin 08 Juli 2019 Pukul 10.00 Wib. 
Media Komunikasi dan Informasi Hukum dan Masyarakat

pengusaha guna terciptanya ketenangan kerja dalam berusaha.

2. Implementasi perlindungan hukum terhadap pekerja dalam hal kebebasan berserikat di PT. Mara Jaya Perkebunan Batu Rata Kecamatan Bangun Purba sudah terlaksana sesuai dengan telah terbentuknya organisasi serikat serbundo tersebut dengan ketentuan Undang-undang RI Nomor 21 Tahun 2000 Tentang Serikat Pekerja dan Undang-undang RI Nomor 13 Tahun 2003 Tentang Ketenagakerjaan.

3. Hambatan pelaksanaan dalam hal kebebasan berserikat terhadap pekerja PT. Mara Jaya Perkebunan Batu Rata Kecamatan Bangun Purba adalah hambatan internal faktor seperti sumber daya manusia, kurangnya komunikasi, minimnya dana. Hambatan eksternal yaitu hambatan dari perusahaan dikarenakan tidak diberikannya ijin oleh perusahaan PT. Mara Jaya Perkebunan Batu Rata Kecamatan Bangun Purba dalam hal kebebasan berserikat, maka dari itu pimpinan serikat pekerja $\mathrm{PT}$. Mara Jaya Perkebunan Batu Rata Kecamatan Bangun Purba mengambil tindakan untuk diselesaikan di dinas ketenagakerjaan,

\section{B. Saran}

1. Agar PT. Mara Jaya Perkebunan Batu Rata Kecamatan Bangun Purba harus menjalankan kewajibannya untuk melindungi setiap pekerja yang bekerja di perusahaannya sesuai dengan peraturan perundang-undangan untuk memahami hakhak para pekerja yang seharusnya pekerja dapatkan, dan memberikan kebebasan kepada pekerja yang ingin ikut serta berorganisasi serikat pekerja tanpa dihalang-halangi dan diacam.
2. Agar PT. Mara Jaya Perkebunan Batu Rata Kecamatan Bangun Purba memakai peraturan perusahaan, tidak hanya menggunakan peraturan managemen sendiri, karena setiap pekerja memiliki kebebasannya untuk ikut serta dalam organisasi serikat pekerja dan menjalankan kebebasannya untuk berorganisasi demi mencapai kesejahteraan, kehidupan yang layak, terpenuhinya hak-hak normatif buruh, memberikan perlindungan, melakukan pembelaan hak dan memperjuangkan kepentingannya.

3. Agar PT. Mara Jaya Perkebunan Batu Rata Kecamatan Bangun Purba memberikan kebebesan kepada pekerja untuk membentuk serikat pekerja dan ikut serta menjadi anggota, sehingga pekerja dapat memperjuangkan hak-haknya dan menyampaikan pendapatnya sehingga tercipta hubungan industrial yang harmonis antara pengusaha dan pekerja.

\section{DAFTAR PUSTAKA}

\section{A. Buku}

Adrian Sutedi. Hukum Ketenagakerjaan, Sinar Grafika, Jakarta, 2009.

A. Masyur Effendi, Hak Asasi Manusia, Dimensi Dinamika dalam Hukum Nasional dan Internasional, Ghalia Indonesia, Jakarta, 2011.

Asri Wijayanti, Hukum Ketenagakerjaan Pasca Reformasi, Sinar Grafika, Jakarta, 2009.

Bahder Johan Nasution, Hukum Ketenagakerjaan Kebebasan Berserikat Bagi Pekerja, Mandar Maju, 2004.

Bambang Sunggono., Metode Penelitian Hukum, PT. Raja Grafindo Perkasa, Jakarta, 2003. 
Media Komunikasi dan Informasi Hukum dan Masyarakat

Chairuddin K Nasution dan Fauzi Chairul F, Hukum Perburuhan (Suatu Pengantar), FH. UISU, Medan, 2003.

Djumadi, Hukum Perburuhan Perjanjian Kerja, Raja Grafindo Perkasa, Jakarta, 2005.

Eko Wahyudi, Hukum Ketenagakerjaan, Sinar Grafika, Jakarta, 2016.

Frans Magnis Suseno, Etika Politik, PrinsipPrinsip Moral Dasar Modern, Gramedia, Jakarta, 2011.

F.X Djumialdi, Perjanjian Kerja, Sinar Grafika, 2010.

G. Kartasapoetra, Hukum Perburuhan Bidang Pelaksanaan Kerja, Bina Aksara, Jakarta, 2005.

Hardijan Rusli, Hukum Ketenagakerjaan, Ghalia Indonesia, Jakarta, 2004

Ida Hanifah Lubis, Pengantar Hukum Ketenagakerjaan di Indonesia, Ratu Jaya, Jakarta, 2009.

Lalu Husni, Pengantar Hukum Ketenagakerjaan Indonesia, Raja Grafindo Persada, Jakarta, 2011.

Maimun, Hukum Ketenagakerjaan Suatu Pengantar,.Pradnya Paramita, Jakarta, 2013.

Philipus M Hadjon, Perlindungan Hukum Bagi Masyarakat Indonesia, Bina IImu, Surabaya, 2003.

Saiful Anwar., Sendi-Sendi Hubungan Pekerja Dengan Pengusaha, Fakultas Hukum UISU, Medan, 2007.

Sandjun H. Manulang, Hukum Ketenagakerjaan Indonesia, Rineka Cipta, Jakarta, 2001.

Satjipto Rahardjo. Penegakan Hukum Suatu Tinjauan Sosiologis, Genta Publishing, Yogyakarta, 2007.

Sentanoe Kertonagoro, Gerakan Serikat Pekerja, Studi Kasus Indonesia dan Negara-Negara Berkembang, Yayasan TKI Indonesia, 2009.
Sukarno, Pembaharuan Gerakan Buruh di Indonesia dan Hubungan Perburuhan Pancasila, Alumni, Bandung, 2009

Yunus Shamad, Hubungan Industrial di Indonesia, Bina Sumber Daya Manusia, Jakarta, 2005.

Yusuf Subkhi, Perlindungan Tenaga Kerja Alih Daya (Outsourcing) Perspektif Undang-undang No. 13 Taun 2003 Tentang Ketenagakerjaan dan Hukum Islam, Maliki, Malang, 2012

Zainal Asikin, Dasar-Dasar Hukum Perburuhan, Raja Grafindo Persada, Jakarta, 2007.

Zaeni Asyhadi, Hukum Kerja : Hukum Ketenagakerjaan Bidang Hubungan Kerja, RajaGrafindo Persada, Jakarta, 2007.

\section{B. Peraturan Perundang-Undangan}

Undang-Undang Dasar Negara Republik Indonesia Tahun 1945.

Undang-Undang Nomor 13 Tahun 2003 tentang Ketenagakerjaan.

Undang-Undang Nomor 21 Tahun 2000 tentang Serikat Pekerja/Serikat Buruh.

Undang-Undang Nomor 39 Tahun 1999 Tentang Hak Asasi Manusia.

C. Internet/Jurnal

Bahder Johan Nasution, "Fungsi Kebebasan Berserikat Bagi Pekerja Dalam Hubungan Industrial Pancasila", Jurnal Inovatif, Volumen Nomor 1 Tahun 2015.

Siti Anik, "Perlindungan Hukum Terhadap Tenaga Kerja Dan Pengusaha Dalam Menjalankan Perusahaan", http://eprints.ums.ac.id.jurnal.pdf, diakses 13 Mei 2019. 